malarial fever is unknown on the spot, but a man may turn over the ground in certain marshy localities and get fever certainly whenever he does so. It was common experience in India that the drinking of certain water, such as that from the highly malarious Western Ghaut forests, would inevitably cause malarial fever.

In many malarious localities, especially parts of China, it is sufficient to turn the ground over to apparently poison the atmosphere and induce malaria in those who are near. There is a medically authenticated case of fever being contracted from newly turned-up earth carried in baskets by coolies past a window. When this and other cases come to be re-examined they may be found traceable to mosquito-born Hæmamoebidæ; but it is difficult to account for them all in this way, and, as I mentioned, there seems to be an opinion amongst Northern men here that all cases of malarial fever cannot be attributed to Anopheles infection.

D. E. Hutchins.

Conservator of Forests, Cape Town, January I9.

\section{Audibility of the Sound of Firing on February $x$.}

I ENCLOSE a record of the sound of the guns heard at Eastbourne, commencing at $3 \mathrm{~h}$. $14 \mathrm{~m}$. and ending at $3 \mathrm{~h} .57 \mathrm{~m}$. As you will see, the sounds came with great regularity every minute, but the period which the sound covered in each minute gradually fell off from eleven to about five seconds. My observations were checked by a friend, and we were stationed on the summit of a down some 500 feet above sea level with a clear sea horizon out to Newhaven. The distance to the Solent is about sixty-five miles, and there was a slight wind from the North-West. I should like to try to describe the sounds which, though faint, were perfectly distinct-er-er-er-pup-er-er-pup-pup, the detonation sound being more marked towards the end of exch period. I need not say that the sounds were indescribably mournful to listen to.

H. D. G.

\section{Audibility of the Sound of Firing on February ist.}

\begin{tabular}{|c|c|c|c|c|c|c|c|}
\hline \multicolumn{2}{|c|}{$\begin{array}{l}\text { Sound com- } \\
\text { menced at }\end{array}$} & $\begin{array}{r}\text { Sound } \\
\text { ended at }\end{array}$ & & $\begin{array}{l}\text { Duration } \\
\text { of sound }\end{array}$ & $\begin{array}{l}\text { Sound com- } \\
\text { menced at }\end{array}$ & \multirow[t]{2}{*}{$\begin{array}{l}\text { Sound } \\
\text { ended at }\end{array}$} & $\begin{array}{l}\text { Duration } \\
\text { of sound }\end{array}$ \\
\hline & & & & & & & \\
\hline 314 & 7 & 314 & 18 & II & $33^{6}$ I I & $\begin{array}{llll}3 & 36 & 15\end{array}$ & 4 \\
\hline 315 & 8 & 315 & 19 & I I & 337 II & $\begin{array}{lll}3 & 37 & \end{array}$ & 4 \\
\hline 316 & 8 & 316 & & IO & $33^{8} \quad 10$ & 33816 & 6 \\
\hline 317 & 8 & 317 & & I I & 339 10 & $\begin{array}{lll}3 & 39 & 17\end{array}$ & 7 \\
\hline 318 & 8 & 318 & & I I & 340 I I & $\begin{array}{lll}3 & 40 & 15\end{array}$ & 4 \\
\hline 319 & 8 & 319 & 19 & I I & $34 \mathrm{I} \quad 10$ & $\begin{array}{lll}3 & 4 & \text { I }\end{array}$ & 5 \\
\hline \multirow{4}{*}{\multicolumn{5}{|c|}{$\begin{array}{l}\text { Observations interrupted by the } \\
\text { rumbling of the wheels of a } \\
\text { cart about a quarter of a mile } \\
\text { distant. }\end{array}$}} & 34210 & $\begin{array}{lll}3 & 42 & 15\end{array}$ & 5 \\
\hline & & & & & 343 I0 & $343 \times 5$ & 5 \\
\hline & & & & & 344 10 & 344 I5 & \\
\hline & & & & & Observation & again inte & pted. \\
\hline 323 & II & 323 & 19 & 8 & 346 II I & 346 I4 & 3 \\
\hline 324 & 12 & 324 & 19 & 7 & 347 10 & $347 \quad 16$ & \\
\hline Observa & ation & again & broke & en by & $\begin{array}{lll}3 & 48 & 9\end{array}$ & 348 I5 & 6 \\
\hline soun & ads & a dista & int car & & $\begin{array}{lll}3 & 49 & 9\end{array}$ & 349 I 5 & 6 \\
\hline 327 & 13 & 327 & I9 & 6 & 350 10 & 35015 & 5 \\
\hline 328 & I3 & 328 & & 5 & Failed to & & \\
\hline 329 & II & 329 & & 6 & growing fe & er and ver & cy faint. \\
\hline 330 & I I & 330 & 16 & 5 & $\begin{array}{lll}3 & 52 & 1\end{array}$ & 35216 & 0 \\
\hline 331 & 12 & $33 \mathrm{I}$ & 16 & 4 & 35310 & 353 15 & 5 \\
\hline 332 & 12 & 332 & $13(?)$ & I & 354 I I & $\begin{array}{lll}3 & 54 & 14\end{array}$ & 3 \\
\hline 333 & 12 & 333 & 16 & 4 & Report & ontinued & \\
\hline 334 & II & 334 & & 4 & $357-\mathrm{bu}$ & impossi & e to tir \\
\hline 335 & II & 335 & & 4 & & very fai & \\
\hline
\end{tabular}

Sensational Newspaper Reports as to Physiological Action of Common Salt.

IN the interest of the dignity of scientific research I venture to hope you will print the following statement. Some American papers have recently published sensational and absurd reports of physiological theories and experiments whose authorship they attributed to me. These reports, which in America nobody takes seriously, were reprinted and discussed in European papers. I hardly need to state that I am in no way responsible for the journalistic idiosyncrasies of newspaper reporters and that for the publication of my experiments or views I choose scientific journals and not the daily Press.

The University of Chicago, Physiological JACQUES LOEB. Laboratory, January 16.

No. 1633 , voL. 63 ]

\section{The Publication of Books without Dates}

Is it not time that men of science should raise a protest against the publication of books without a date on their titlepage? This is a practice which has been common to maps and a certain class of books of reference, and it comes, to my mind, very near to being a deliberate fraud, as it seeks to pass off as new that which is more or less obsolete. We should surely do our utmost to prevent this habit from spreading to scientific beoks, such as the translation of van 't Hoff's "Physical Chemistry," which is reviewed in NATURE of February 7 .

Central Institution, Exhibition Road, February 9.

O. HENRICI.

\section{Optical Illusion.}

IT seems to me certain that the phenomenon illustrated in NATURE of February 7 (p. 353) is due to (I) fatigue, the cause of the reversed image seen when one looks away from the diagram on to white paper, combined with (2) involuntary and iniessant slight movements of the eye.

Of course the reversed image, white squares and black lines, when one looks away on to white paper, is well known. With me it does not appear to occur at once, but after an interval; and it is intermittent, fading and recurring several times.

Now, when one gazes at the diagram, the eye moves incessantly to a slight extent; and so it is only the central part of the images of the white spaces that fall always on parts of the retina continually fatigued ; the edges, near the black squares, fall on parts of the retina that have, on the whole, a good deal of rest owing to the fact that they are occupied for half the time (or so) by the images of the black squares. I do, in fact, see dark lines along the central portions of the white spaces, and the dark patches spoken of are where these dark lines cross.

I can make the horizontal dark lines disappear by purposely giving my eyes a more than slight movement up and down the vertical white spaces. Then the vertical shadowy lines, in the middle of these spaces, remain; the horizontal dark lines vanish, as should be the case.

As regards the "vanishing" of a patch looked at, I do not find this to be a correct account of what I observe. I notice that when I suddenly gaze at any one crossing, the crossing dark lines and dark patch at that place take longer to appear; but they do appear in time. Perhaps the "yellow spot" is slower in action than the rest of the retina in questions of fatigue? But these phenomena are difficult to observe, as the eyes soon tire. A very noticeable phenomenon, I suppose an extreme case of fatigue, is the following. When I gaze for a long time, white spaces here and there disappear altogether in a fitful manner, the squares concerned for the time blending. This occurs with monocular vision as well as binocular, as do all the phenomena mentioned. But I think the eyes must be very tired for this to occur.

As regards the question of spacing, I imagine that the steadier the eye-muscles, and so the less the involuntary movements, the narrower might be the white spaces. I have noticed a violet margin round an orange on snow, due to the same causes. It increased when the orange was rolled. The explanation is obvious if the view taken above is right. W. LARDEN.

R.N.E. College, Devonport.

\section{Some Animals Exterminated during the Nineteenth Century.}

Re the very interesting article published under the abovementioned title by Mr. R. Lydekker (p. 252, January 10), may I indicate and correct an error? Camptolaemus labradorius is certainly exterminated on the North Atlantic coast of America, as Mr. Lydekker says; but this breed still exists not very far off, but in a somewhat out-of-the-way place, in the island of Anticosti, where M. Paul Combes saw it recently, as he states the fact in his "Exploration de l'Ile d'Anticosti," I896 (J. Andrè, publisher, Paris). HENRY DE VARIGNY.

Paris.

IN reference to the foregoing letter, it may be mentioned that the duck in question is entered as extinct in the "A.O. U. Check-list of North American Birds," 2nd ed. p. 56 (1895), and no information has subsequently reached this country as to its alleged survival in Anticosti. 